Temporary Migrants, Partial Citizenship and Hypermigration*

Rainer Bauböck, European University Institute

Florence, March 2011

Abstract:

Temporary migration raises two different challenges. The first one is whether territorial democracies can integrate temporary migrants as equal citizens; the second is whether transnationally mobile societies can be organised democratically as communities of equal citizens. Considering both questions within a single analytical framework will reveal a dilemma: on the one hand, liberals have good reasons to promote the expansion of categories of free moving citizens as the most effective and normatively attractive response to the problem of partial citizenship for temporary migrants, yet, on the other hand, if free movement rights were actually used by too many, this might fatally undermine the sustainability of intergenerational and territorial democratic polities.

Keywords:

Temporary migration, partial citizenship, free movement, hypermigration, life-course perspective

1. Introduction: The temporary migration dilemma

This paper will consider two challenges raised by temporary migration. The first one is whether territorial democracies can integrate temporary migrants as equal citizens; the second is whether transnationally mobile societies can be organised democratically as communities of equal citizens. Considering both questions within a single analytical framework will reveal a dilemma: on the one hand, liberals have good reasons to promote the expansion of categories of free moving citizens as the most effective and normatively attractive response to the problem of partial citizenship for temporary migrants, yet, on the other hand, if free movement rights were actually used by too many, this might fatally undermine the sustainability of intergenerational and territorial democratic polities.

Political theorists who address the question of what liberal states owe to outsiders have focused on two categories: immigrants who become long-term residents and external populations residing permanently in other countries. The normative salience of distinguishing between non-citizen residents and noncitizen non-residents seems clear enough. On the one hand, states have special duties towards immigrants who settle in their territory, which on many accounts include granting them certain cultural rights and eventually offering them full citizenship status. On the other hand, states have general duties of global justice towards human beings outside their border and may also have special duties towards external populations who are particularly affected by their decisions and policies. Temporary migrants,

\footnotetext{
* Preprint Draft. A revised version of this paper has been published in Critical Review of International Social and Political Philosophy, vol. 14, no. 5, December 2011: 665-693.
} 
however, sit on the border between these two categories and therefore the duties that states have towards them seem less clear.

The temptation is to avoid this difficulty by assigning temporary migrants to either one or the other group. For example, in a pioneering statement, Michael Walzer condemned European guestworker policies of the 1960s and 1970s as a tyranny of citizens over aliens and demanded that immigrants must be set on the road to citizenship (Walzer 1983: 62). This view is broadly shared by liberal theorists, but tacitly assumes that temporary migrants become long-term immigrants, as most of the European guestworkers actually did. The alternative view is to assimilate temporary migrants into the broader category of non-citizen non-residents. If temporary migrants are admitted on a contractual basis, then host state duties towards them seem reducible to honouring universal human rights and special contractual rights. In this view, there is nothing special about temporary migrants, since the same rights would also have to be respected for non-citizens residing in other states with which a government concludes a contract. Alternatively, temporary migrants may also be regarded as if they were external populations from a global distributive justice perspectives by considering how admission for temporary employment can provide many more with better opportunities than they enjoy in their countries of origin and may also benefit those who stay behind through remittances migrants send home (Chang 2003; Bell 2005; Ruhs 2006).

Temporary migrants may eventually become immigrants, but this is not inevitable. Most want to return to their countries of origin and many eventually do so However, as long as they stay they are not outsiders or mere transient visitors either. We call them migrants if, unlike tourists, they take up residence, education or employment. These purposes of their stay make their autonomy and well-being in significant ways dependent on the opportunities and rights they are offered in the host society. If this society is committed to domestic standards of social equality and non-discrimination, then it cannot take the situation in the migrants' countries of origin as reference point. Temporary migrants are often willing to accept conditions of work, housing, public education or health care far below the domestic standards the receiving society sets for its citizens. They often even accept conditions that are worse than before departure in their countries of origin as long as this serves their long-term life plan of improving their situation after return (Ottonelli and Torresi 2010). ${ }^{1}$ Their apparent consent cannot be a sufficient reason for tolerating exploitative and discriminatory treatment of temporary migrants. They must be clearly included when assessing a system of rights by a criterion of social justice, such as Rawls' difference principle that considers how the system affects the worst off group.

Yet temporary migrants who are foreign nationals are still partial citizens. ${ }^{2}$ Some employment benefits and social rights that depend on long-term residence do not apply to them (Carens 2008a). And, most importantly, they cannot and do not claim equal political participation and representation in the making of the laws to which they are subjected in the host country. The reason is that citizenship in independent states is constructed as a life-long membership that is acquired at birth and passed on across generations through descent or birth in the territory. This intergenerational nature of state membership would be severely disrupted if immigrants could acquire citizenship automatically by taking up domestic residence or if emigrants would automatically lose their citizenship by taking up residence abroad. Intergenerational citizenship is thus characterized not only by automatic birthright acquisition 
but also by the absence of strict ius domicilii, i.e. automatic acquisition or loss as a result of a mere change of residence. First generation immigrants have to apply for naturalisation and first generation emigrants lose their citizenship only through explicit renunciation or through withdrawal for other reasons than mere residence abroad.

The intergenerational character of state citizenship has been regarded as morally problematic by some political theorists. ${ }^{3}$ In contrast, I consider birthright membership as morally defensible and indeed functionally required for the formation of stable political communities with a potential for comprehensive self-government. While, as will be discussed in section 5 below, non-state political communities with more fluid memberships are possible and do already exist in the present world, a general demise of intergenerational citizenship would radically change the conditions for building and sustaining liberal democracy.

The intergenerational character of state citizenship explains why foreign national temporary migrants can be only partial citizens in their host country. It also implies that they remain citizens of their country of origin while residing abroad and can even pass on this citizenship to children born there. So the diagnosis of partial citizenship for temporary migrants has to be modified by considering not only the context of reception but also the context of origin. However, even if all states involved provide temporary migrants with those rights to which they are morally entitled, these still would not add up to a status of full and equal citizenship. Countries of origin whose nationals these migrants remain have to grant them a right to return, to diplomatic protection and, arguably, also an absentee franchise since temporary absence does not justify a presumption that these migrants have weaker stakes in the democratic process than current residents. Yet external citizenship (Bauböck 2009) still is a merely partial membership when compared with the status of domestic citizens. In polities constituted as territorial jurisdictions, residence inevitably makes a difference both with regard to the extent of subjection to the laws and with regard to the rights attached to citizenship status. Moreover, neither the right to return nor the absentee vote serves to overcome the lack of temporary migrants' representation in the polity where they reside and work. On the contrary, the unconditional duty of countries of origin to readmit their citizens may make these more vulnerable to threats of deportation in the host state, which in turn reinforce their exploitability by employers and landlords. So, from this perspective, temporary migrants seem to be inevitably partial citizens in both countries of origin and destination.

This conclusion is, however, premature. I have so far assumed that in relation to their host country temporary migrants are foreign nationals. Yet many migrants enjoy citizenship rights in a destination country because they were born abroad with an inherited foreign citizenship, because they are citizens of the European Union making use of their free movement rights, or because they have acquired dual citizenship through naturalisation and can then also move freely between a country of origin and destination. For these temporary migrants, the partial citizenship they enjoy vis-à-vis their countries of origin is supplemented by full (or, in the case of mobile EU citizens, nearly full) citizenship status in a destination country and it is exactly the combination of these statuses that provides them with opportunities for unrestricted temporary migration. 
While foreign national temporary migrants are partial citizens in the sense of lacking the protection that depends on full citizenship status, free moving migrants may still be seen as partial citizens in the different sense of lacking a sense of belonging that sustains civic virtues. They are unlikely to actively participate in the self-government of a polity in which they reside only temporarily, even if they have all the rights and opportunities to such participation. This leads me to consider the second challenge of temporary migration. If the numbers of free movers became very large, how would this affect active participation and political cohesion in territorially structured democracies?

The two different kinds of partial citizenship for restricted and free temporary migrants are still connected through a common cause - a lack of strong affiliation that could either justify a fuller set of rights or motivate fuller participation. Analysing both categories of temporary migrants within a single analytical framework thus reveals a dilemma. Liberals have good reasons to promote the expansion of categories of free moving citizens as the most effective and normatively attractive response to the problem of partial citizenship for temporary migrants because, from a liberal perspective, freedom of movement has both instrumental and intrinsic value (Carens 1992), and because access to citizenship status and rights provides temporary migrants with the best possible protection against discrimination and exploitation. However, if expanded free movement rights were actually used by too many this might undermine the cohesion of intergenerational and territorial polities and active forms of civic participation.

I will start with a conceptual clarification of different meanings of temporary migration and will then present in section 3 a typology of empirical varieties ranked on a normative scale of freedom. Section 4 discusses the limitations of strategies that promote full citizenship for temporary migrants. Section 5 considers first a hypothetical world where temporary migration is free and most individuals are temporary migrants and examines then whether in the real world urban and supranational polities already provide alternative models of citizenship that are better able to integrate temporary migrants than state-based citizenship regimes. In my conclusions I suggest that if the dilemma cannot be fully resolved, we might do best by switching back and forth between the perspective of preserving intergenerational citizenship in territorial polities and a life-course perspective on migrants' citizenship transitions.

\section{Unpacking temporariness}

Nearly all empirical as well as normative literature on temporary migration deals only with one specific type among a broader range of phenomena covered by this concept. These are public policy programs by destination states that provide migrant workers with temporally limited - and in most cases nonrenewable - work permits. The U.S. bracero program of the 1940s and 1950s and guestworker programs in Germany and several other European states in the 1960s and early 1970s are the best know examples. These programs are today generally seen as failures, mainly because of the incapacity of liberal democracies to prevent permanent settlement and family reunification. Evidence that it is indeed constraints on state power in liberal constitutions which explain this outcome is provided by the contrasting cases of temporary migrant workers in the Arab Gulf states, where the rotation of temporary migrants has been effectively enforced through depriving these of basic liberties and 
segregating them from mainstream society. Recently, however, the idea that well-managed circulatory migration can produce win-win-win outcomes for destination and sending countries as well as for migrants themselves has been revived in both the U.S. and Europe (GCIM 2005; Castles 2006; Ruhs 2006; Vertovec 2007).

Some deeper normative puzzles about temporary migration remain invisible as long as we look only at programs designed by destination states. A first step towards a broader view is to consider the different meanings of the adjective 'temporary'. It can be understood as referring to an objective social fact, to subjective expectations, or to normative constraints. The first and most obvious interpretation refers to de facto temporary residence of migrants in a destination country that ends after a specified time through return or onward migration to other destinations. In this demographic sense, all immigration is initially temporary. Long-term immigration can be distinguished from temporary migration only retrospectively after a specific time period determined by social or legal convention. Those who have left before that time had been temporary, while those who stayed on are not. A different interpretation of what 'temporary' means refers instead to the future and to migrants' intentions to leave the country after a certain time or to the expectations of resident populations that they will do so. Finally, migration may be temporary in the sense that the duration of their stay is limited by legal or moral norms. Legal norms can positively establish the legitimacy of temporary residence or negatively prohibit the continuation of such residence. Moral norms are invoked primarily when disputing the normative validity of such legal permissions and prohibitions and when proposing alternative justifications for temporary admission or permanent residence rights. We arrive thus at altogether five distinct meanings of temporariness: (1) demographically objective, (2)subjectively intended, (3) collectively expected, (4) legally prescribed and (5) morally justified.

These conceptual distinctions draw our attention to several potential mismatches that generate social conflicts, political disputes and moral dilemmas. Subjective intentions of migrants about the length of their stay frequently change over time and can then conflict with non-corresponding expectations in the wider society about their departure. Non-renewable temporary residence permits as a condition for legal admission may conflict with a moral principle of consolidation of residence according to which the right to stay grows stronger with the duration of stay. This conflict between legal and moral norms will turn into a political one, when there is also a growing mismatch between public policy and demographic reality. In most liberal states the phenomenon of the 'guests who stayed' has triggered policy revisions through renewals of limited residence permits and amnesties for those who entered without permission or overstayed. In some cases, however, the original policy goal was reasserted through offering financial incentives for return migration ${ }^{4}$ or through expulsions even after long residence periods. Much less discussed is a converse incongruence between normative and objective temporariness. Some migrants enjoy a full right to permanent residence already when they are admitted but many among them do not intend to stay for long and may de facto leave after a short period.

Both types of mismatches are not simply odd combinations that occur accidentally, but are systematically generated by causal mechanisms that are well-known in migration studies but generally ignored in migration policy making. The quip that "there is nothing more permanent than temporary foreign workers" (Martin 2001) is supported by several explanations. The individual migrant who has 
been admitted only for a limited period but wants to retain access to the job market of the host country will not return if she risks being shut out in the future. The employer who has recruited temporary migrants who perform well will try to retain them rather than change them for new ones whom she does not know. Employers also prefer informal recruitment strategies through the family networks of already employed migrants to formal recruitment procedures monitored by governments, and family reunification will in turn consolidate the settlement process of temporary migrant workers. Finally, the shutting down of guestworker admission programs in Europe in the mid 1970s further reduced incentives for return migration and triggered preemptive family reunification. It is therefore much more likely that more migrants will stay only temporarily where such legal conditions and constraints are largely absent and migrants can freely enter, take up jobs and remain indefinitely. Under these conditions, even subjectively intended long-term stay may result in de facto temporary migration if the economic opportunities in the host country decline or those in the country of origin improve. This has been, by and large, the experience with free movement of workers from other member states in the European Union.

My intention here is, however, not to provide a full explanatory account of how the different modes of temporariness are causally linked with each other, but to prepare the ground for a normative argument: Transforming guests who want to stay into citizens who are ready to leave is the best available liberal response to the dilemmas of temporary migration, but this strategy raises itself a new dilemma of how to secure sufficient levels of democratic continuity and participation in transnationally mobile societies.

\section{Five types of temporary migration}

From a normative perspective we can now distinguish different empirical types of migration according to the degrees of freedom of movement and the extent of equality that migrants enjoy compared to permanent residents and citizens.

\section{(1) Irregular migrants}

The first category are irregular migrants. ${ }^{5}$ Their presence is by definition temporary in the negative legal sense since they have no permission for further residence and are under an obligation to leave. Matters are a bit more complicated when we start to look closer at the various categories covered by the term irregular migrant. Some enter the country without permission. Their legal freedom of movement is constrained in two senses: they had no legal right to enter and are under a legal duty to exit. Others have entered through regular channels, as tourists, guest workers, foreign students, asylum seekers or family members of residents but have subsequently lost permission to stay. Some among these are overstayers who extend their residence beyond a time limit defined as a condition for admission. Others have been admitted without a specific time limit, but circumstances have changed thereafter: their asylum applications were turned down or they were separated from an "anchor" spouse by death or divorce.

States respond to the presence of irregular migrants in three alternative ways: through expulsion efforts, de facto toleration or regularization. Only the latter response transfers irregular migrants into one of the other categories that will be discussed below. Apart from the strong constraints on their 
freedom of movement and right to stay, irregular migrants are also in the most precarious position with regard to other rights. In liberal democracies they are of course not without rights, but these will be either reduced to a minimum set of basic human rights (including due process and humane treatment in case of deportation) or, if more extensive, will remain insecure and difficult to claim because of the looming deportation threat (Bosniak 2006).

The question that is relevant for my present concern is whether irregular migration should sometimes be regarded as an acceptable form of temporary migration with the implication that it ought to be tolerated in liberal democracies. My answer to this is negative. Irregular status is unacceptable not just because it undermines the rule of law, but also because of the constraints on basic freedoms and the precariousness of rights to which it exposes migrants. All arguments against second class status for regular temporary migrant workers apply a fortiori to official toleration of irregular migrants. Once we agree that this status is undesirable, we can also use this judgment as a further objection against the global redistribution argument for temporary migrant worker programs. Assuming a given level of economic demand for immigrant workers, a state that turns a blind eye to irregular immigration provides economic opportunities to more migrants than a state that regulates and thereby constrains access to temporary migration. So why not let market forces determine the demand for temporary workers and maximize the number of migrants by minimizing their rights? ${ }^{6}$

If we reject such a diabolic case for irregular migration, then toleration can only be defended on pragmatic grounds, such as a lack of state enforcement power or a lack of democratic support for expulsion or regularization. From a liberal perspective, the conditions for choosing between these remaining two alternatives are also fairly clear. Expulsion can be legitimate only as long as migration may still be considered objectively temporary, i.e. before a threshold of long-term residence has been reached. Within this period, states may decide on humanitarian or pragmatic grounds to offer irregular migrants regularization or a chance to apply for immigration after returning to their countries of origin. Beyond the threshold of permanent residence, individuals acquire a moral claim to regularization (Carens 2008b; 2009). What is less obvious is whether the irregular period of residence has to count fully towards entitlements to equal treatment with regard to those rights that are generally reserved for permanent residents, or towards residence requirements for naturalization. Considerations of fairness towards regular migrants ought to permit some discounting of periods of irregular status.

\section{(2) Controlled admission with return conditionality}

The guest worker programs discussed above belong to a second type of migration that is also legally temporary, however in the different sense of being attached to a regular residence permit that has a fixed expiry date and is generally non-renewable. There is thus an expectation in the destination country that migrants admitted under such programs will actually return to their countries of origin at the end of the predetermined period. Generally, this expectation matches also the subjective intentions of the migrants concerned, although these may change over time as they find that their earning targets are harder to reach than imagined - often because of high costs of living. 
Freedom of movement is again constrained here both at entry and with regard to the right to stay, but with the important difference that admission is now based on a contract: the authorities of the destination state agree to admit the migrant if she agrees to the conditions of admission and return. The contract itself is rather asymmetrical, since the destination country can dictate conditions and temporary migrants have de facto few choices among alternative destinations. In the case of direct recruitment of guest workers in the country of origin, their choice is of the take-it-or-leave-it kind. Nearly all temporary migrant worker programs exploit this contractual asymmetry to impose further conditions beyond the time limit of the residence and work permits, such as tying the latter to employment in a particular company or in a particular kind of job. As argued extensively by Carens, such conditions always reinforce the economic exploitability and social vulnerability of temporary migrant workers (Carens 2008a).

Yet it would be wrong to conclude that all temporary admission programs are indefensible. In principle, foreign worker programs could be designed in a way that removes any conditionality apart from the limited residence permit. Moreover, temporary migration for employment is also not the only temporary admission program and the picture looks a bit brighter when we consider these other programs. International students also get temporary residence permits that usually expire with the completion of their university courses. They may be charged higher tuition fees and be prohibited from seeking employment in the regular labour market, but inside the university their position is in most schemes equal to that of native students. As in the case of migrant workers, their circumstances can change, for example if they marry a citizen of their host country and acquire then a claim to permanent residence. With growing global competition for highly skilled migrants, host country governments now often consider also whether they should enforce return migration or rather offer successful international students a permanent residence option. As with guestworker programs, temporary admissions therefore often result in long-term settlement. However, this does not imply that international students should generally be admitted on a permanent basis. What makes temporary admission legitimate in their case is that the purpose of their stay is an activity that has a natural end (the completion of their studies), that the activity is carried out within an institution that keeps them in many ways separate from the larger society without enforced segregation, and that they receive a service - often in exchange for high international student fees.

Refugees who are granted temporary protected status (TPS) form a third category of temporarily admitted foreign citizens. A number of states in North America and Europe have introduced TPS in order to address large scale refugee movements triggered by wars and civil wars and to circumvent individual procedures for determining asylum status according to the 1951 Geneva Refugee Convention (GRC). In this context, TPS becomes then a flexible alternative approach to refugee flows that destination countries feel obliged to take in. The logic of TPS is that it responds to a major violent conflict in a specific country or region of origin and ends as soon as the crisis is over and the host country government deems the situation safe for return. TPS permits may be renewed or extended until this is the case, but the purpose of the program is to prevent permanent settlement and enforce return migration. 
The legitimacy of TPS programs is more difficult to assess than that of guestworker programs, which are generally problematic, or international student programs, which are generally not. First, given increasingly restrictive asylum policies, TPS can certainly respond effectively to some of the most urgent demands for refugee intake. However, the specific demand for TPS is often created by previous government decisions to constrain access to full asylum status. Second, the duration of a refugeegenerating crisis is hard to foresee and the evaluation of conditions for safe return should not be left to governments that have a vested interested in enforcing it. Third, after some time temporary refugees, just like guestworkers, become permanently settled immigrants, and an initial condition that their admission is only for the purpose of temporary protection becomes then morally irrelevant.

\section{(3) Controlled admission with initial temporary status}

The third type of temporary migration that we need to consider is when admission is initially temporary but a transition towards permanent residence is built into the conditions from the very start. European guestworker programs evolved in this way when destination countries that were hungry for more foreign labour started to issue renewals of permits that had been designed to be non-renewable. Systems of work and residence permits were then gradually adjusted to introduce conditions for renewal, change of employers and family reunification. Among these conditions were adequate income and housing and a continuous employment record. Similar responses have also been developed in traditional countries of immigration. For example, the U.S. has an Adjustment of Status procedure that allows temporary residents to apply for permanent residence status (aka a Green Card) without leaving the country. Since the 1970s most European states with a longer immigration experience have developed immigration programs that foresee a regular option of transition from temporary to permanent residence. In 2003 the EU brought about a harmonization of conditions for the general transition from temporary to permanent residence permits for non-EU immigrants. There is now a distinct status of EU long-term residents for which third country nationals can apply after five years and that allows them also to move to other Member States (Council Directive 2003/109/EC). Most recently, the European Union has created a Blue Card (Council Directive 2009/50/EC) that provides highly skilled immigrants with a work permit valid throughout the EU (except in Britain, Denmark and Ireland where the directive does not apply) for initially up to two years, but renewable thereafter.

Adjustment of status for guest workers and temporary residents implies, on the one hand, an acknowledgement that programs designed for strictly temporary stay need a correction mechanism that takes de facto settlement into account. Programs like the EU Blue Card, on the other hand, select immigrants for presumptive long-term residence but force them to pass through a probationary stage during which their right to stay is still temporary. Initially temporary admission is problematic if the rights enjoyed by non-permanent residents are unduly constrained or if the conditions for permanent settlement are onerous. These criteria may lead to a negative assessment of current policies in Europe, which have recently supplemented conditions of sufficient income and housing with 'integration tests'. These tests require knowledge of a dominant language or the country's history, constitution and values not merely for naturalisation but already for access to permanent residence (Guild, Groenendijk et al. 2009; Kostakopoulou, Ersboll et al. 2010). ${ }^{7}$ Such problematic hurdles are, however, not an intrinsic feature of programs that allow for a gradual transition from temporary to permanent residence. If the 
only requirement were a clean criminal record during a period of residence of no more than five years, then granting labour migrants initially only temporary instead of permanent residence permits would be hardly objectionable. Doing so may also correspond to the subjective intentions of migrants who do not know at the point of admission whether they will stay indefinitely and who can answer this question only after some experience with work and life in their host society.

Under these conditions, the main constraint on migrants' freedom in this category does not concern their right to stay permanently but their right to enter. Migrants who arrive with initially temporary permits under the various European points or quota systems do not exercise free movement, but, similar to guestworkers, are selected mainly for the purpose of satisfying economic demand in the country of destination. For those who pass this test, a mutually beneficial immigration contract that includes the promise of easy transition to permanent residence does not give rise to major concerns about unfair treatment. That transition will, however, never be so smooth for the second subcategory discussed here whose initial status had been irregular or who had been admitted on strictly temporary contracts. The recent European trend to test and select immigrants for family reunification, permanent residence and citizenship can be explained, but not justified, by a widespread perception that most longterm immigrants had not initially been invited to stay for good.

Asylum seekers whose claims are examined after they have crossed the border form a third subcategory. During the asylum determination procedure their stay is temporary and will become permanent only once they have been recognised as refugees according to the GRC. In case of a negative decision they lose their residence permit and are liable to be deported. However, enforcing return is difficult in three cases. First, they cannot be sent back if their country of origin cannot be identified or if that country refuses to cooperate through readmission. Second, even if they cannot satisfy a narrow interpretation of the GRC definition of refugees, they may still be protected against deportation to a country of transit or origin by non-refoulement clauses, such as Art. 33 of the GRC or Art. 3 of the European Convention on Human Rights, which has been interpreted by courts as prohibiting extradition to countries where they would face torture or inhuman or degrading treatment or punishment. Finally, if the asylum determination procedure has gone through several instances and has lasted for several years, then the individuals concerned will have acquired a claim to be treated as immigrants, whose right to stay no longer depends on the circumstances of their admission.

(4) Controlled admission for permanent residence

Traditional immigration countries outside Europe have for a long time operated programs (the U.S. quota system, the Canadian and Australian point systems) under which immigrants are selected but enjoy immediate permanent residence status when admitted. There is also an expectation that these immigrants will adopt the citizenship of their country of settlement. Such programs hardly exist for economic migrants in Europe and the number of immigrants who fit this category has been declining also in the U.S. and Canada, where transition from temporary to permanent status is now more common. 
However, admission for immediate permanent residence is still very important for other types of immigrants. In particular, close family members of permanent resident foreigners or of citizens of the host country have a strong claim to reunification in that country without a specific time limit to their residence permits or handicaps in their access to employment opportunities. As with the status of permanent residents, the EU has also brought about a significant harmonisation of family reunification (Council directive EC/86/2003). This directive foresees that family members admitted for purposes of reunification shall obtain residence permits of the same duration as those already held by their sponsors, shall enjoy the same rights of access to employment, and that residence permits for spouses, unmarried partners and minor children become independent of their sponsor's permit after five years.

There is once again a group of refugees that fall within the category discussed here. The USA, Canada and Australia have comparatively large-scale programs for refugee resettlement. Different from TPS and individual asylum procedures, refugees admitted for resettlement are selected already outside the host country, mostly in refugee camps close to their region of origin, and are then accepted as permanent immigrants. The selection process does not exclusively refer to their refugee condition, as would be ideally the case in asylum determination procedures, but is frequently driven by economic and political interests of the country admitting them.

Why should immigrants selected for permanent residence be considered as a relevant category on a normative scale of temporary migration? The answer is that even those who have a right to stay for good may decide to return or move on. So legal permanence can still be combined with intended and de facto temporariness. This is somewhat less likely to be the case among the immigrants discussed here when we compare them with the fifth category of free movers discussed below. Among those selected for permanent residence there is a presumptive fit between their purpose of immigration and the receiving state's willingness to accept them as part of its future resident and citizen population. But circumstances can change. As long as they are foreign residents, immigrants remain exposed to the threat of deportation if they come into conflict with the law, including those laws that apply specifically to foreign residents only. Permanent resident foreigners also lose their status if they spend too much time abroad, for example in order to take care of family members in a country of origin. Finally, immigrants may find conditions for settlement and integration harder than they had imagined or opportunities much better somewhere else. We must therefore consider a possibility that seems a converse of the third category discussed above. Just as a stay that is initially temporary may become permanent after some time, so a stay that is initially intended to be permanent may turn out to be temporary after all.

(5) Free admission for long-term residence

The final category on our scale contains the freest migrants. These are individuals whose movement is neither constrained at admission nor with regard to their right to stay. Political theorists usually consider only internal migration as being free in this dual sense and assume that all international migration is exposed to migration control. But this is a myopic view. Surprisingly large and growing flows are exempted from such controls. The first and most obvious subcategory for which this is true are returning 
citizens. Under international law, every state is obliged to unconditionally admit its own citizens to its territory. ${ }^{8}$

Many citizens who enjoy this right of free admission are in fact not returnees, but immigrants in the proper demographic sense of the term, since they were born abroad and have inherited a citizenship from their parents that provides them with a free admission ticket in a country where they have never resided. All contemporary states embrace a principle of ius sanguinis for 'second generations' born abroad at least until the age of majority. A significant number of states go much further by permitting that citizenship can be passed on across generations without limits (de Groot and Vink 2010). Large emigration flows in the past combined with strong versions of ius sanguinis create therefore large extraterritorial populations who can claim a citizenship-based right of free admission for permanent residence. Finally, extraterritorial citizenship can be acquired not only by birth but also by naturalisation. The nationality laws of many states offer naturalisation to foreign spouses of citizens, to former citizens and their descendants, or to groups considered as belonging to the nation in an ethnocultural sense without any residence requirement.

In certain cases, co-ethnics are also granted admission without having previously acquired citizenship abroad, but with an expectation that they will do so shortly after arrival. The German Aussiedler policy and the Israeli Law of Return are the best-known examples of unconditional admission of co-ethnics towards whom the 'homeland' has a specific duty of protection. These are, however, certainly not the only states with preferential admission of co-ethnics (Joppke 2005). I do not want to discuss here the democratic legitimacy or liberal justifications for such policies (see Bauböck 2009), I merely want to point out the empirical relevance of this category.

A second subcategory of migrants enjoys even wider free movement and permanent residence rights than those who can make use of an external citizenship. Dual or multiple citizenship creates a right of free movement back and forth between several states and of unconditional residence in each of these. Growing toleration of dual citizenship is one of the strongest trends in the evolution of nationality laws since the last quarter of the $20^{\text {th }}$ century. All liberal democracies now accept dual citizenship when it is acquired at birth by descent from parents with different nationality or through the combination of ius soli and extraterritorial ius sanguinis. A shrinking number still require renunciation of a previous citizenship as a condition for naturalisation. The trend towards toleration of dual citizenship obtained through naturalisation is fed by two quite different policy goals: countries of immigration want to remove renunciation requests as the biggest obstacle for immigrant naturalisation, while states that wish to retain economic, cultural and political ties with their 'diasporas' no longer withdraw their citizenship in case of acquisition of a foreign one (Faist and Kivisto 2007; Blatter, Erdmann et al. 2009).

While dual citizenship creates personalised zones of free movement between two states that recognise a particular individual as their citizen independently of each other, the third subcategory of free movement emerges from contracts between states that grant each others' citizens free admission for the purpose of long-term residence. The most prominent example is the European Union in which citizens of member states have extensive rights to enter, reside and work in the other member states. These rights are not fully unconditional. On the one hand, governments can decide to impose temporary 
restrictions on the citizens of new accession states with regard to access to employment. ${ }^{9}$ On the other hand, residence rights of EU citizens remain conditional on comprehensive sickness insurance coverage and on not becoming a burden for the social assistance system of the host state. EU citizens can also be expelled when they constitute a threat to public order, but every expulsion order must be examined individually and the measure must be proportional, which implies that the duration of previous residence must be taken into account. The same residence rights and conditions are extended to third country national family members of EU citizens and apply also to international students from other EU countries (European Parliament and Council Directive 2004/38/EC). The European Union is not the only example of a free movement zone that offers long-term residence rights to the citizens of particular other states. Britain and Ireland formed until 1997 a common travel area without passport controls and both states still grant each other's citizens free admission and indefinite leave to remain. Similarly, since 1954, the Nordic Passport Union has allowed citizens of Denmark, Iceland, Norway, Finland and Sweden to freely enter and stay in any of the other countries.

Regional unions of this kind create the strongest potential for normatively unconstrained and subjectively intended temporary migration. Circulatory migration may be even more free for multiple citizens since states cannot impose any conditions on readmission, but the selection criteria used for awarding citizenship refer to presumptively lasting genuine ties, which reduces somewhat the likelihood of temporary migration as a purely opportunity seeking activity. Specifically, a second citizenship acquired through long-term residence will generally enhance the likelihood of future residence. Migrants with genuine ties to several countries whose citizenship they possess may de facto move frequently back and forth, but each temporary stay remains embedded in a longer-term biographical trajectory. Instead of perceiving their stay as temporary, they may therefore rather consider their absence as a temporary interruption of long-term residence. By contrast, in the case of regional unions, freedom of movement is not granted as a recognition of multiple ties that connect migrants to several countries. Citizens of the EU enjoy freedom of movement simply by virtue of being citizens of a country that subscribes to a reciprocal international agreement. Compared with multiple citizenship that results from previous migration, the effect of such regional agreements is that freedom of movement is granted to large populations most of whom are unlikely to make actual use of it. Those who do are also more likely to be purely opportunity seeking migrants who rarely develop lasting ties to their host society and see little point in acquiring its citizenship. Free movement in regional unions of states is therefore the condition under which a right to permanent residence will most often lead to intended, expected and de facto temporary migration.

\section{Enhancing citizenship for temporary migrants}

Apart from irregular status, the other four types of temporary migration discussed in the previous section can be regarded as normatively acceptable in the sense that it is possible to define conditions under which the states involved would not commit any moral wrong in offering these statuses. This condition of justifiability can be achieved if temporary migrants are granted a set of rights and liberties that protect not only their human and contractual rights but meet the special responsibilities that the states involved have towards them. From this perspective, the normative problem to be resolved falls largely within the domain of non-ideal theory. Knowing that many states fail to adequately respect the 
rights of temporary migrants, we have to work out strategies that apply under real-world assumptions and that could improve the protection of temporary migrants until it meets the required standards. This problem will be most acute for migrants of type two and will gradually vanish as we move up the scale of freedom towards those enjoying free movement and permanent residence rights. A concern about rights deficits for temporary migrants explains therefore why most theorists have focused on guestworker programs, virtually ignoring all other types of temporary migration.

If we consider an absence of human rights protection for temporary migrants as the main problem, then the obvious political response is to promote migrants' workers rights through international law. This effort has led to the 1990 International Convention on the Protection of the Rights of All Migrant Workers and Members of Their Families (ICRMW), which contains a comprehensive list of rights of both regular and irregular migrants and came into force in 2003. However, no major receiving country of migrants has so far ratified the ICRMW. The failure of this convention highlights that a human rights response is in several ways insufficient. Highly developed states that host large numbers of migrants do not object to guaranteeing them human rights and claim that these are already protected under their domestic constitutions and other international legal instruments. The general problem is that sending and receiving states of migrants produce partial citizenships for non-resident citizens and non-citizen residents independently of each other. Many more states adhere to international conventions on the rights of refugees and stateless persons because these groups have been deprived of effective citizenship protection by their countries of origin. By contrast, temporary migrants are external citizens of one state and temporary residents of another and each country regards itself as sovereign in regulating these statuses. This does not exclude bilateral agreements between sending and receiving states. When European countries recruited guestworkers they concluded many such agreements, but these reflected the interests of the states involved and did not establish new international human rights standards.

The unwillingness of states to provide adequate human rights for temporary migrants and to coordinate their rights provision with each other is a serious problem, but it does not address what we have identified as the basic distinction between the five categories, which is their freedom to enter and remain indefinitely in a country of destination. At least in the present world, these are not universal rights of human beings, but special rights of citizens. ${ }^{10}$ Another goal might then be to expand the spaces of citizenship in such a way that many more temporary migrants are included. This could be achieved through broader acceptance of dual citizenship or through further enlargement of the European space of free movement and the creation of similar unions in other parts of the world.

Both strategies have important merits and have had much greater success than attempts to promote international rights of temporary migrants. In Europe, America and Oceania, the number of states that require that naturalisation applicants must renounce a citizenship of origin or that withdraw their nationality if their citizens acquire a foreign one, is shrinking rapidly. As a result many more individuals enjoy today free movement between at least two states that have to admit them unconditionally. However, there are significant normative constraints on pursuing this strategy. Citizenship as membership in a particular state presupposes a genuine link between an individual and that state. ${ }^{11}$ Temporary migration itself cannot create a sufficiently strong link that would justify a claim to 
citizenship. Therefore, temporary migrants must first become long-term residents before they can obtain their host country's citizenship. Where citizenship can be easily acquired without any genuine link, as is the case in states offering their passports to big investors or to third and later generations of emigrant descent, citizenship loses its intrinsic value as membership in a self-governing political community and is reduced to its instrumental value of facilitating free movement. The normative constraint is here on the state's offer of citizenship, not on individual choice. Persons who meet a criterion of genuine links may apply for citizenship for entirely instrumental reasons without citizenship being thereby devalued through over-inclusion, since the benefits of membership will then still be granted only to those who have a prior claim to inclusion.

The second strategy of promoting regional unions has also brought some spectacular results. The last two rounds of EU accession have not only regularized large numbers of temporary migrants from Central and Eastern Europe but have provided them additionally with free movement and political representation rights. EU enlargement is, however, again, only a partial solution to the problem how to make temporary migration free. Just as individuals must qualify for citizenship status through particular links to the country concerned, so countries must qualify for joining an economic and political union of states. Apart from the 1993 Copenhagen criteria of democracy, the rule of law, human rights, protection of minorities, a functioning market economy and acceptance of the aims of political, economic and monetary union, there is an additional implicit condition that only neighbouring states ${ }^{12}$ can join the EU, which is after all a regional union rather than a Kantian world confederation of free republics. One could then still hope for a replication of supranational unions with internal free movement in other continents, which would eventually provide all human beings with a supranational citizenship that complements their national ones and that provides them with opportunities for temporary migration in other states under conditions of free admission and indefinite residence. Even this politically very remote but normatively attractive goal would, however, leave temporary migration across the external borders of such unions in significant ways less free.

All the obstacles discussed so far may be considered as problems within non-ideal theory. This is obvious for states' unwillingness to agree on a set of rights for temporary migrants. But also the difficulties of expanding citizenship or regional unions beyond qualifying candidates would no longer arise if free movement could be disconnected from citizenship status altogether. In an ideal world individuals could move freely across international borders but would still have to take up long-term residence before they can apply for a new citizenship. Similarly, regional unions could remain externally bounded and reserve political rights for the citizens of their member states, but would become open for temporary migration from third countries.

Valeria Ottonelli and Tiziana Torresi have recently argued against such attempts of 'liberal inclusivists' to relegate the temporary migration problem to non-ideal theory (Ottonelli and Torresi 2010). They criticize liberal 'rights fetishism' by pointing out that temporary migrants are vulnerable not only because they lack adequate protection of their rights in the host society, but also because temporary migrants whose life plans are oriented towards return are unlikely to claim citizenship rights and make effective use of them in the destination country. In Ottonelli's and Torresi's view, offering them inclusion in the host country cannot overcome their lack of protection there if the migrants' own sense of self- 
respect is oriented towards the country of origin. The reason is that rights do not have the same meaning and importance for those whose social bases of self-respect do not coincide with the political space of the jurisdiction in which they reside only temporarily.

This is an important insight, but it needs to be unpacked. I find Ottonelli's and Torresi's argument not so convincing with regard to the protective rights dimension of citizenship, but very pertinent for its active participatory dimension. A liberal inclusivist could respond that Ottonelli and Torresi misconstrue the space of rights by considering only destination countries. If we identify a transnational space of free movement as the most adequate space of rights for temporary migrants and promote multiple citizenships and regional unions within this space, then there is no more mismatch with the social space of self-respect within which temporary migrants attribute meaning to their rights. This latter space may be narrower than the former but it is embedded rather than disconnected. Dual citizens enjoy both internal and external citizenship and EU free movers are citizens of the Union as well as of their countries of origin. In this respect, there is not much difference between internal temporary migration within a large state and within the European Union. In both cases migrants tend to accept working conditions that are shunned by locals and refrain from claiming their rights if they regard their migration as merely temporary and driven by short term income goals. Since internal free movement within states is not considered as giving rise to a significant mismatch between spaces of rights and of self-respect, building supranational spaces of free movement seems an adequate response to concerns about the protection of temporary international migrants. The deeper worry raised by Ottonelli's and Torressi's argument is that the perceived intrinsic value of citizenship of the European Union or of what we might call 'dual passport citizenship' will be generally rather low. These migrants are therefore likely to remain passive citizens protected by rights that they do not help to create through active democratic participation. Providing citizenship rights for temporary migrants may indeed not be a satisfactory answer in this respect if temporary migrants care little about citizenship in the first place.

The second limitation of Ottonelli's and Torresi's argument is that they focus on individual temporary migration projects that create a disjuncture between a social space of self-respect and a political space of rights without considering the structural implications of large-scale temporary migration for the institution of democratic citizenship itself. I will explore in the next section whether the inclusion of temporary migrants requires a fundamentally different model of citizenship that is no longer territorial and intergenerational and will then conclude by suggesting the need for a complementary individual perspective of life-course citizenship that addresses the concerns raised by Ottonelli and Torresi.

\section{A hypermigration dystopia and alternative citizenship models}

The United Nations Population Division estimates that currently less than four per cent of the world population are international migrants, i.e. persons who have lived for more than one year outside their country of birth (United Nations 2006). This statistic does not include seasonal circulatory migration, but twelve months are generally not considered long-term residence, so most temporary migrants who engage in continuous work will be included in the four per cent estimate. 
Imagine now a radically different world in which most people are temporary migrants for most of their lives. Assuming for a moment that the current system of territorial jurisdiction of states and intergenerational citizenship remains in place, the effect would be that in most countries a majority of citizens would be non-residents and a majority of residents would be non-citizens at any given point in time. Let us call this hypothetical scenario a hypermigration world. ${ }^{13}$ I suspect the impact on democracy would be quite dramatic. When Henry Sidgwick considered the conflict between a cosmopolitan principle of open borders and the need for patriotic sentiments, he suggested that "...the casual aggregates that might result from perfectly unrestrained immigration would lack internal cohesion (Sidgwick 1897: 308). As liberal nationalists today, Sidgwick was mostly concerned about the effect of long-term immigration on a shared public culture that is seen to support citizens' social solidarity and democratic deliberation (e.g. Miller 1995). I think that Sidgwick's worries apply more plausibly to an increase of temporary migration precisely because it does not lead to intensive interactions and cultural changes that affect both natives and migrants. In liberal societies the transformation of national cultures through immigration is nothing to be regretted. And long-term settlement of immigrants generates an expectation of mutual adaptation between natives and newcomers that will never be free of conflicts but that promotes also a search for shared interpretations of the citizenship which unites them as members of the polity. By contrast, hypermigration would not only undermine civic solidarity among accidental co-residents but the very preconditions of citizenship as an institution.

The primary reason for this conclusion is that intergenerational territorial citizenship acquired at birth and for life would no longer be sustainable. Ius soli would no longer make sense, since the fact of birth in the territory could no longer serve as a proxy for an expectation of future residence. With free movement for everyone in the hypermigration world, the right of return, which sustains this expectation for emigrants in the present world, would become meaningless. Ius sanguinis would lead to an even stronger disconnection between territorial population and citizens by descent, most of whom would be born abroad and would never take up long-term residence in the territory of the state whose citizens they are. Citizenship acquired by descent would become just a label derived from one's family tree rather than an allocation mechanism for a status that unites citizens across generations. The only plausible rule for determining who is a citizen in such a world is ius domicilii. Citizenship would be acquired automatically after a short time of residence and also lost automatically when moving on to a different state.

Replacing intergenerational citizenship with a purely residential one would have profound consequences for the structure of democratic life. Territorial populations would indeed become "casual aggregates" of migrants who happen to reside currently in any given territorial jurisdiction but each of whom knows that most others around had not been here for a long time and are not likely to be here in a few years. Such aggregates are not a sufficient basis for self-governing democratic polities, whose citizens authorize the making of laws to which they will be subjected and agree to long-term public investments for the sake of future generations' well-being and the general flourishing of the polity. Temporary coresidents will, however, still have interests in the provision of a public infrastructure that enables them to be mobile and in the preservation of security and public order and could therefore agree to be taxed and subjected to laws that pursue this goal. But their interest in representation by elected lawmakers 
and in holding public authorities accountable would be greatly diminished. A libertarian or semiauthoritarian government that provides a public infrastructure and security without interfering too much with the private business and lives of residents would probably emerge as the system of political rule that best responds to popular interests.

On the other hand, the human desire for belonging and recognition within a self-governing community of equals is too strong to dissipate completely even in a hypermigration world. Civil society could then become the space where forms of pseudo-citizenship are recreated. Non-territorial associations with stable and intergenerational memberships could substitute many of the public goods currently provided by states to residents with club goods provided by associations to members only. A world that produces hypermigration would also have communication and transportation technologies that make it easy to build and maintain strong forms of self-government within such associations. Some associations could be formed on the basis of social class to secure the provision of services such as quality education for one's children or quality health care for one's parents. Others might emerge on the basis of shared ethnic or religious identities. Many of these associations could be internally democratic and some might establish powerful monopolies in the provision of basic goods that reduce exit options for their members and create a form of subjection that closely resembles government in territorial states.

In contrast with Sidgwick's fear, the major difference to the contemporary world would not be a devastating increase of cultural diversity, but a loss of heterogeneity within these non-territorial polities, whose members would be self-selected to be similar to each other in their interests, identities and ideologies. In a hypermigration world there could be little solidarity across these dividing lines, apart from a shared Hobbesian interest in a political power that is able to preserve public order and territorial mobility.

A purely hypothetical scenario like this one does of course not show that temporary migration at its current pace and volume is in any way corrosive for democratic citizenship as we know it. I have pointed out that at the end of section 3 that the expansion of free movement regimes is likely to lead to less permanent immigration and more intended, expected and de facto temporary migration. Yet the corrosive effects of hypermigration depend on the share of temporary migrants in the total population rather than in the migrant population. Spaces for free movement can be more easily expanded when economic and political disparities between countries that provide structural push and pull factors are reduced. Under these conditions it is more plausible to expect a decline in the overall volume of migration together with an increase in the relative share of temporary migration.

I have introduced the hypermigration dystopia for three reasons. First, it highlights the implicit background assumptions that we tend to make when considering the political integration of migrants. We see them as integrating into stable territorial polities with comprehensive powers, intergenerational citizenship and largely sedentary populations. These conditions are, however, historically contingent facts rather than logical necessities and they might change over time. If and when this happens, the transformation of democracy will be as radical as in the transition from direct democracy in small city states to representative democracy in large territorial states. 
Second, some developments in contemporary civil society point towards a loss of integrative power of state-based democracy and a trend towards alternative provision of public goods, such as education or health care, as club goods for internationally mobile elites. This trend is caused by a neoliberal dismantling of social citizenship more than by a rise in temporary migration but it is significant that high income migrants develop a demand for the kind of non-territorial provision of club goods that can be expected as a general pattern in the hypermigration scenario.

Third, regimes of purely residential citizenship exist also in present democracies at substate levels and they might be considered as alternative real world models of polities that are fully adapted to the integration of temporary migrants as equal citizens. In contrast with the situation in authoritarian states, such as China, or semi-democracies, such as Russia, where internal migration is still heavily regulated, municipalities and provinces in democratic states are generally open for free internal migration within a state territory. The right of free internal movement is not tied to citizenship but constructed as a human right of all legal residents. ${ }^{14}$ Substate polities are not only open for territorial admission and residence for citizens and non-citizen residents alike, they also lack any separate system of intergenerational determination of citizenship by birthright or naturalisation. Since only a few countries explicitly mention provincial or local citizenship in their constitution, it might seem odd to use the concept of citizenship in this context. However, historically, cities were the cradles of citizenship long before the emergence of the modern state. Moreover, conceptually it makes sense to consider substate entities as self-governing polities wherever local and regional governments enjoy substantive autonomous powers and are democratically elected by residents (Bauböck 2003). If cities and provinces have citizens, then there must also be a rule to determine who these citizens are. And this rule is clearly automatic ius domicilii, or residence-based citizenship. In most current democratic states, this basic rule is constrained with regard to political citizenship by the state-level regime. Voting in local and regional elections presupposes then national citizenship. In Europe, however, 13 of the 27 EU member states and two nonmember states (Norway and Iceland) have introduced a local franchise that is purely residence-based and includes third country nationals.

Steven Vertovec and other scholars studying migration and ethnic diversity have pointed out that 'superdiverse' metropolises provide social, economic and cultural spaces in which migrants are no longer minorities facing native sedentary majorities (Vertovec 2007). To a certain extent these cities provide also politically open and integrative spaces for temporary migration. One might therefore ask whether my picture of the hypermigration dystopia was not painted too black. If cities can be governed democratically based on a regime of residential citizenship in spite of large 'floating populations' of temporary migrants, why should this not be possible for states?

The sceptical answer to this question is that global metropolises may have gained considerable autonomy vis-à-vis national governments in economic and cultural matters, but remain politically dependent and embedded in the larger states where they are located. And if superdiverse cities became independent states they would also adopt an intergenerational citizenship regime. Apart from these 'realist' reservations, there is also a normative concern. If my assumption about a universal human desire for intergenerational membership in political communities is correct, then residential citizenship 
in substate polities should be properly seen as complementing state level intergenerational citizenship without replacing it.

The formula "complementing without replacing" was also adopted in the 1997 EU Amsterdam Treaty in order to clarify the relation between EU citizenship and national citizenship of the member states. In contrast with local citizenship, supranational citizenship in the EU is derivative from member state nationality rather than from residence. While EU enlargement has widened the space for free temporary migration, third country nationals and their descendants can acquire supranational citizenship only through birth or naturalisation in one of the member states. Some migrant associations, academic scholars and EU policy makers have proposed to offer migrants from outside the EU an independent residence-based access to EU citizenship. This reform would risk undermining a basic feature of the union. The derivative nature of supranational citizenship is not a defect, but adequately reflects the constitutional architecture of a union constituted by its member states. A generalised form of residential citizenship at the EU level would, moreover, greatly exacerbate problems that are already manifest now and that the hypermigration scenario has served to highlight. EU citizenship is quite strong with regard to rights and most of these rights depend explicitly on making use of the free movement privilege by taking up residence in another member state. But EU citizenship has no specific legal duties attached to it. National governments have repeatedly rejected proposals to introduce even a modest EU income tax. Finally, citizenship practices are particularly weakly developed, as low and declining voter turnouts in European Parliament elections illustrate. In many ways, EU citizenship is already now a "citizenship light" (Joppke 2010). Severing its link with member state nationality would make it much lighter still and would therefore merely serve to speed up the pace of institutional adaptation to hypermigration, which would eventually also make territorial democracy harder to sustain.

6. Conclusion: Stretching the spaces of citizenship and switching between perspectives on migration I have explored how democratic citizenship may be reformed to include temporary migrants and how temporary migration could transform the institutions of democratic citizenship. My conclusion is that the dilemma I have sketched at the beginning cannot be completely resolved. Fully integrating temporary migrants as equal citizens in territorial polities is difficult since generalised temporary migration is likely to undermine the very structure of territorial citizenship.

Political liberals can hardly stop critical reflection with a diagnosis of this kind. The question raised, but not answered, by Ottonelli and Torresi is how temporary migrants experience the various citizenship statuses they occupy during their itineraries and what could be done to enable them not merely to claim rights but also to gain self-respect and recognition by others.

If institutional solutions are inevitably imperfect, then what is needed may be a change of perspective that does not only take the political community as reference point and unit of analysis, but also individual migrants themselves. In addition to the strategies of stretching the spaces of citizenship that I have discussed in sections 3 and 4, we should promote a switching back and forth between two alternative views of migration. From the perspective of states, temporary migrants come and leave their 
territories, but from the perspective of temporary migrants states enter and leave their lives (see Bauböck 1998).

This Gestaltswitch enriches, first, our epistemological horizon. Taking migrants' life-courses as units of analysis implies a shift from a static and spatial view of migration towards a dynamic and temporally structured one. Second, it widens our normative horizon too. Instead of asking what is needed to make temporary migrants equal with the sedentary citizens of their host or home countries, we can then consider what could make temporary migrants full citizens over the course of their lives. This may sound like an excuse for accepting partial citizenship, but some temporary loss of rights, if voluntarily incurred, could indeed be accepted if it leads eventually to multiple citizenship with its entailed rights of free movement.

The main normative implication of the perspectival switch would, however, not be any specific policy recommendations, but rather the search for a public 'fusion of horizons' between sedentary populations whose citizenships and political identities are determined by a stable set of nested (local, provincial, national and supranational) polities and mobile populations whose lives and political identities are shaped by multiple citizenship status transitions.

Note on Contributor

Rainer Bauböck holds a chair in social and political theory at the Department of Political and Social Sciences of the European University Institute, Florence. His fields of research are normative political theory and comparative research on citizenship, European integration, migration, nationalism and minority rights. He is co-director of the EUDO observatory on citizenship at: http://eudo-citizenship.eu.

Acknowledgements

Draft versions of this paper were presented at a conference of the Association of Legal and Social Philosophy on 9 April 2010 in Southampton University, at a GRITIM-UNESCO workshop on the Ethics of Migration at Pompeu Fabra University Barcelona on 26 April 2010, and at a conference on Citizenship and Civil Society: Cosmopolitan Challenges on 10 December 2010 at Sun Yat-sen University, Guangzhou. I am very grateful to Chris Armstrong, Andrew Mason, David Owen, Valeria Ottonelli, Andrei Stavila and Tiziana Torresi for generous and helpful written comments on a first draft. 
${ }^{1}$ See Stark (1991: 87-166) for a microeconomic model confirming that migrants may rationally accept a temporary decline of income in order to reduce relative deprivation in contexts of origin.

${ }^{2}$ Citizenship is often thought of as an all or nothing matter, so that individuals can either be citizens or noncitizens, but not partial citizens. One can distinguish three core dimensions of citizenship as a membership status, as a bundle of legal rights and duties, and as a set of ethical virtues and practices. Whereas membership seems conceptually a dichotomous category (you have it or you don't), the strength of citizenship rights or practices is often measured by degrees and these dimensions can also be disconnected from membership status. I use the term partial citizenship, however, in relation to all three dimensions. Individuals are partial citizens when they are deprived of certain core rights of citizenship, when they lack incentives and dispositions for civic participation, and when they are considered as partial insiders and partial outsiders (see also note 10 below).

${ }^{3}$ Joseph Carens famously claimed that from a perspective of global justice, birthright citizenship is like a feudal status (Carens 1987; 1989). Ruth Rubio Marín proposed that long-term residents should automatically be turned into citizens because the imperative of democratic inclusion of all subjected to the laws overrides migrants' right to choose between alternative citizenship statuses (Rubio-Marín 2000). Dora Kostakopoulou suggests that a general system of civic registration should replace citizenship by birth or naturalisation (Kostakopoulou 2008). Ayelet Shachar calls for a birthright privilege levy that compensates the citizens of poor countries for the undeserved outcome of the birthright lottery (Shachar 2009) and Jackie Stevens regards the principle of birthright membership as the main cause of endemic violence in the international state system (Stevens 2010).

${ }^{4}$ See e.g. the largely failed German efforts in the early 1980 s to promote return migration of guestworkers through financial incentives.

${ }^{5}$ Like Joseph Carens, I prefer the term 'irregular migrants' because it is less heavily laden (Carens 2008b: 164) than alternative terms, such as 'Illegal migrants', which attributes illegality to persons as such instead of their actions, or 'undocumented migrants', which conceals the fact of law breaking by suggesting that these migrants merely lack documents.

${ }^{6}$ On the rights numbers trade-off in migration see Martin and Ruhs (2008).

${ }^{7}$ Immigrants' basic knowledge of a dominant language is clearly in their own interest as well as in the interest of citizens whose mother tongue that language is. This may justify language tests both at the threshold to permanent residence and to naturalisation, as long as immigrants are offered sufficient opportunities and incentives for learning this language. What is objectionable are tests that are designed to deter immigrants from applying for improved legal status or to select immigrants according to their educational background.

${ }^{8}$ Of course, this right too is not universally honoured, as some regimes practice various forms of banishment of dissidents or ethnic cleansing. Non-cooperation with readmission requests in case of deportation amounts also to non-compliance with this universal duty.

${ }^{9}$ The transition period for free access to the labour market for eight of the 2004 accession countries, which is currently still fully imposed by Germany and Austria, will end in May 2011; for Bulgaria and Rumania it may last until 2014.

${ }^{10}$ Unconditional rights to stay and return are a defining characteristic of citizenship as nationality in the current international state system. This does not rule out that some non-nationals can also enjoy fairly strong rights to 
admission and permanent residence. The fact that EU citizens and some categories of co-ethnic immigrants are granted mobility rights that approximate those of national citizens does not illustrate that these rights can be easily disconnected from citizenship status, but rather that citizenship status itself is no longer strictly tied to nationality. Foreign nationals who are granted unconditional rights to stay and return are quasi-citizens rather than privileged non-citizens.

${ }^{11}$ See the judgment of the International Court of Justice in the Nottebohm case (1955 I.C.J. 4). I defend a broader stakeholder principle that all those and only those should be recognised as citizens whose life-courses link their interests in autonomy and well-being to the self-government and flourishing of a particular polity (see Bauböck 2009).

${ }^{12}$ The condition is not one of strict contiguity, since otherwise the UK, Ireland, Greece, Sweden and Finland could not have joined, but of geographic location within a broader European region, the borders of which are partly renegotiated through the process of European integration itself.

${ }^{13}$ The term hypermobility has been introduced by human geographer John Adams (2005) to refer to the increasing ease and distance of spatial mobility (in spite of constant numbers of people travelling). I am here not interested in spatial mobility as such but in migration across political borders and specifically in the effect of increasing numbers of people involved in such migration. This is why I introduce the term hypermigration here.

${ }^{14}$ Universal Declaration of Human Rights, Art. 13(1); International Covenant on Civil and Political Rights, Art. 12(1).

\section{References}

Adams, J. (2005). Hypermobility: A Challenge to Governance. New Modes of Governance: Developing an Integrated Policy Approach to Science, Technology, Risk and the Environment. C. Lyall and J. Tait. Aldershot, Ashgate: 123-138.

Bauböck, R. (1998). The Crossing and Blurring of Boundaries in International Migration. Challenges for Social and Political Theory. Blurred Boundaries. Migration, Ethnicity, Citizenship. R. Bauböck and J. Rundell. Aldershot, Ashgate: 17-52.

Bauböck, R. (2003). "Reinventing Urban Citizenship." Citizenship Studies 7(2): 137-158.

Bauböck, R. (2009). "The Rights and Duties of External Citizenship." Citizenship Studies 13(5): 475-499.

Bell, D. A. (2005). Justice for Migrant Workers? Foreign Domestic Workers in Hong Kong and Singapore. Challenging Citizenship: Group Membership and Cultural Identity in a Global Age. S.-h. Tan. Aldershot, Ashgate: 41-62.

Blatter, J. K., S. Erdmann, K. Schwanke (2009) Acceptance of Dual Citizenship:Empirical Data and Political Contexts. University of Lucerne Working Paper Series "Glocal Governance and Democracy" 8: 1-50.

Bosniak, L. (2006). The Citizen and The Alien: Dilemmas of Contemporary Membership. Princeton, Princeton University Press. 
Carens, J. H. (1987). "Aliens and Citizens: The Case for Open Borders." The Review of Politics 49(2): 251273.

Carens, J. H. (1989). Membership and Morality. Admission to Citizenship in Liberal Democratic States. Immigration and the Politics of Citizenship in Europe and North America. R. W. Brubaker. Lanham and London, University Press of America: 31-49.

Carens, J. H. (1992). Migration and Morality. A Liberal Egalitarian Perspective. Free Movement. Ethical Issues in the Transnational Migration of People and of Money. B. Barry and R. Goodin. Pennsylvania, Pennsylvania State University Press: 25-47.

Carens, J. H. (2008a). "Live-In Domestics, Seasonal Workers, Foreign Students, and Others Hard to Locate on the Map of Democracy. Journal of Political Philosophy ." Journal of Political Philosophy 16(4): 419-445.

Carens, J. H. (2008b). "The Rights of Irregular Migrants." Ethics and International Affairs 22(2): 163-186

Carens, J. H. e. a. (2009). The Case for Amnesty. Time erodes the state's right to deport. Boston Review May/June: http://bostonreview.net/BR34.3/ndf_immigration.php.

Castles, S. (2006). Back to the Future? Can Europe meet its labour needs through temporary migration? Fortress Europe. Bonn, Heinrich-Boell Foundation.

Chang, H. (2003). "The Immigration Paradox: Poverty, Distributive Justice, and Liberal Egalitarianism." De Paul Law Review 52. 759-776.

De Groot, G-R. and M. Vink (2010). Loss of Citizenship. Trends and Regulations in Europe. EUDO CITIZENSHIP comparative report 4: 1-53, http://eudo-

citizenship.eu/docs/loss_paper_updated_14102010.pdf.

Faist, T. and P. Kivisto (2007). Dual Citizenship in Global Perspective, Palgrave Macmillan.

GCIM (2005). Migration in an interconnected world: New directions for action, Global Commission on International Migration.

Guild, E., K. Groenendijk, et al., Eds. (2009). Illiberal Liberal States. Immigration, Citizenship and Integration in the EU. Farnham, Ashgate.

Joppke, C. (2005). Selecting by Origin. Ethnic Migration in the Liberal State. Cambridge, MA, Harvard University Press.

Joppke, C. (2010). "The Inevitable Lightening of Citizenship." European Journal of Sociology/Archives européennes de sociologie 51(1): 9-32.

Kostakopoulou, D. (2008). The Future Governance of Citizenship. Cambridge, UK, Cambridge University Press. 
Kostakopoulou, D., E. Ersboll, et al., Eds. (2010). A Redefinition of Belonging? Language and Integration

Tests in Europe. Leiden, Brill/Martinus Nijhoff.

Martin, P. L. and M. Ruhs (2008). "Numbers Vs. Rights: Trade-Offs and Guest Worker Programs."

International Migration Review 42(1): 249-265.

Miller, D. (1995). On Nationality. Oxford, Oxford University Press.

Ottonelli, V. and T. Torresi (2010). "Inclusivist Egalitarian Liberalism and Temporary Migration: A

Dilemma." Journal of Political Philosophy DOI: 10.1111/j.1467-9760.2010.00380.x

Rubio-Marín, R. (2000). Immigration as a Democratic Challenge: Citizenship and Inclusion in Germany and the United States. Cambridge, UK, Cambridge University Press.

Ruhs, M. (2006). "The potential of temporary migration programmes in future international migration policy." International Labour Review 146(1-2): 7-36.

Shachar, A. (2009). The Birthright Lottery. Citizenship and Global Inequality. Cambridge, MA, Harvard University Press.

Sidgwick, H. (1897). The Elements of Politics. London, Macmillan.

Stark, O. (1991). The Migration of Labour. Oxford, Blackwell.

Stevens, J. (2010). States Without Nations. Citizenship for Mortals. New York, Columbia University Press.

United Nations (2006). International Migration Report 2006. A Global Assessment. E. a. S. A. P. Division. New York, United Nations.

Vertovec, S. (2007). "Circular Migration: the way forward in global policy?" International Migration Institute Working Papers(4).

Vertovec, S. (2007). "Super-diversity and its implications." Ethnic and Racial Studies 29(6): 1024 - 1054.

Walzer, M. (1983). Spheres of Justice. A Defense of Pluralism and Equality. New York, Basic Books. 